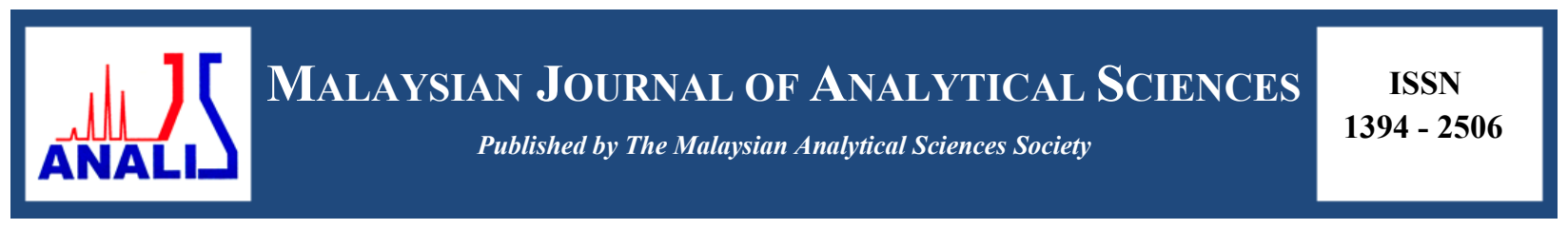

\title{
POLYANILINE MULTI-COATED ONTO POLYVINYLIDENE FLUORIDE AND SILICON ELASTOMER FOR PRESSURE FILTRATION MEMBRANES
}

\author{
(Polianilin Multi-Lapis Bersalut pada Polivinilidin Fluorida dan Elastomer Silikon untuk \\ Membran Penurasan Bertekanan)
}

\author{
Fatimah Ibrahim, Rosiah Rohani*, Abdul Wahab Mohammad \\ Department of Chemical and Process Engineering, \\ Faculty of Engineering \& Built Environment, \\ Universiti Kebangsaan Malaysia, 43600 UKM Bangi, Selangor, Malaysia \\ *Corresponding author: rosiah@ukm.edu.my
}

Received: 21 October 2015; Accepted: 14 June 2016

\begin{abstract}
In this study, silicone rubbers were used to achieve the desire absorbing properties of PANI onto polyvinylidene fluoride (PVDF) microporous support. Poly (methyl-vinyl ether-alt-maleic acid) (PMVEA) polymeric acid was used as acid dopant to enhance the membrane filtration performance. Initially PVDF micro-porous support was dip-coated with silicone rubber elastomer solution followed by deposition with PANI by in-situ chemical oxidative polymerisation techniques using two-compartment cell in presence of PMVEA and ammonium persulfate as the oxidizing agent. The PANI multilayer composite membranes were characterized by gravimetric for PANI content measurement namely Scanning Electron Microscope (SEM), Fourier-Transform Infrared (FTIR), Differential Scanning Calorimetry (DSC) and contact angle. The PANI content was found to be more than 30 $\%$. SEM, FTIR and DSC analysis have confirmed the presence of PANI onto the multilayers membrane while the contact angle of the membrane in presence of high loading PANI was $0^{\circ}$ indicating the super hydrophilicity than without the PANI presence of $78.8^{\circ}$. The pressure filtration of PANI multilayer composite filtration membrane with a range of polyethylene glycols at different molecular weights was obtained based on the high flux up to $904.11 \mathrm{~L} / \mathrm{m}^{2} . \mathrm{h}$ and reasonable molecular weight cut off of below $20,000 \mathrm{~g} / \mathrm{mol}$ were obtained for the synthesized membrane.
\end{abstract}

Keywords: polyaniline, silicone elastomer, polyvinylidene fluoride, chemical oxidative polymerisation, polymeric acid

\begin{abstract}
Abstrak
Melaui kajian ini, getah silikon telah digunakan untuk mencapai keinginan menyerap sifat-sifat PANI ke polivinilidin fluorida (PVDF) sokongan mikrobeliang. Poli (vinil metil-eter-alt-asid malik) (PMVEA) asid polimer digunakan sebagai asid pendopan untuk meningkatkan prestasi penapisan membran. Pada mulanya mikro-berliang sokongan PVDF telah disalut dengan larutan elastomer getah silikon diikuti dengan pemendapan PANI oleh teknik pempolimeran kimia oksidatif sel in-situ menggunakan dua bahagian sel dengan kehadiran PMVEA dan ammonium persulfat sebagai agen pengoksidaan. Membran komposit PANI multilapis telah dicirikan secara gravimetrik untuk mengukur kandungan PANI, seperti Mikroskop Imbasan Elektron (SEM), Inframerah Transformasi Fourier (FTIR), kalorimeter pengimbasan pembezaan (DSC) dan sudut sentuhan. Kandungan PANI didapati melebihi 30\%. Analsis SEM, FTIR dan DSC telah mengesahkan kehadiran PANI pada membran PANI multilapisan manakala sudut sentuhan membran dengan kehadrian PANI yang tinggi adalah $0^{\circ}$ menunjukkan keadaan super hidrofilik berbanding tanpa kehadiran PANI adalah $78.8^{\circ}$. Tekanan penapisan membran komposit PANI multilapis dengan pelbagai julat polietilena glikol pada berat molekul yang berbeza telah diperolehi berdasarkan fluks yang tinggi sehingga $904.11 \mathrm{~L} / \mathrm{m}^{2} . \mathrm{h}$ dan berat molekul yang munasabah iaitu di bawah $20.000 \mathrm{~g} / \mathrm{mol}$ bagi membran yang telah di sintesis.
\end{abstract}

Kata kunci: polianilin, elastomer silikon, polivinilidin fluorida, pempolimeran oksidatif kimia, asid polimer 


\section{Introduction}

Interest in conducting polymer from polyaniline (PANI) has grown due to its conducting properties: electronically conductive and electrochemically active polymer [1], good redox properties and high environmental stability, relatively simple synthesis, and also low cost [2-7]. These advantages have led PANI to be used in numerous applications including filtration membranes [8], battery electrodes [9, 10], electromagnetic shielding devices [11], and anticorrosion coatings [12-14]. To cope with the rising energy costs, emerging contaminants, stricter environmental regulations, and industrial demand, the next generation of filtration membranes must be more selective, robust, and require low chemical and energy inputs. New membrane materials must be explored to meet these goals in applications such as water and wastewater treatment, in addition to other well-established industrial, biomedical and analytical separations [8]. High permeation flux and high selectivity are the essential requirement for successful separation membrane. One way of achieving this is by self-synthesizing filtration membranes that meet the criteria. Additionally this membrane can be tailored utilizing intrinsic polymer such as PANI to meet specific requirement for the targeted application. The fabrication of high-performance multilayer composite membrane specifically from PANI base from microporous support substrate is essential to obtain the most suitable surface structure, roughness and surface porosity for the separation.

Multilayer composite membrane has been reported for various applications especially for water filtration [15-18]. The multilayer composite membrane usually has three layers and can be divided into two types based on the membrane configuration: (selective layer)/(gutter layer)/(support substrate) and (sealing or protective layer)/ (selective layer)/(support substrate) [19-21]. In the former, the selective layer might be as thin as a few tens nanometers and slightly defective; the gutter layer is a permeable material which serves as a channelling and adhesive medium between the selective layer and the support substrate. In the latter, the selective layer is thicker (about $0.04 \pm 1 \mathrm{~mm}$ ) and essentially defect-free. The sealing or protective layer not only functions as a protective layer but also improves the membrane performance [21]. Therefore this motivates the synthesis of the multilayer composite membrane to be used in the field of pressure filtration namely nano- (NF) and ultra-filtration (UF). The used of PANI in forming multilayer composite membranes have been reported in the application of fuel cell [22], desalination of saline water that consists of charged solutes $[17,23]$, separation of carbon dioxide from methane [24] and also as electrochemical energy storage [25]. However the application in pressure filtration membrane under neutral solutes has yet to be reported.

The main aim of this work is to fabricate multilayer composite membrane from PANI coated with silicone elastomer onto PVDF and further characterize it. Multilayer composite membrane is prepared in the form of (sealing or protective layer)/(selective layer)/(support substrate) in series. PANI works as the sealing layer, silicone rubber as the selective layer acts as barrier to attach more PANI onto PVDF (support substrate). Silicone rubber is used for selective support as it has low density, easy to form, good chemical resistance and weather resistant [26]. The functionalization of silicone rubber has been reported can improve the membrane performance either in pervaporation, gas separation or extraction to serve for better separations [27-29]. Chemical oxidative polymerization of aniline is conducted in the presence of $1 \mathrm{M} \mathrm{HCl}$ to dilute the aniline and ammonium persulphate (APS) to form PANI. These aniline and APS solutions further reacted in a specially fabricated two compartment cell, each solution is filled at each side of the cell and the PVDF membrane is sandwiched between the cell. Meanwhile polymeric acid of poly (methyl- vinyl ether-alt-maleic acid) (PMVEA) is used as the dopant for functionalizing the PANI together with $\mathrm{HCl}$. PANI doped with PMVEA was reportedly used for covalent attachment of oligonucleotides through the carboxylic acid functionality [30,31]. The chemical structure of PANI, PVDF, silicone rubber and PMVEA used for producing the multilayer composite membrane is presented in Figure 1.

The characterization of the synthesized membranes was performed using Fourier Transform Infrared (FTIR) spectroscopy. Thermal properties of the membrane were investigated by Differential Scanning Calorimetry (DSC) while surface morphology is investigated by Scanning Electron Microscope (SEM). Drop shape analysis was used to examine surface wettability changes contact angles $(\theta)$ for liquid water droplets on the multilayer membrane surfaces. The performance of the multilayer membrane is tested via rejection of different molecular weights (MW) of neutral and non-charged solutes from Polyethylene glycols (PEG) in a dead-end filtration. Solutions with 
different molecular weight (MW) were used for the identification of the nominal pore sizes of the membrane fabricated $[32,33]$.

a)

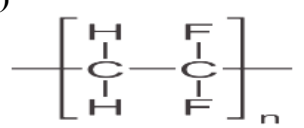

c)

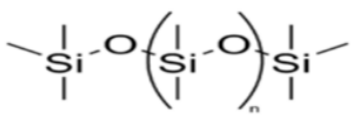

b)

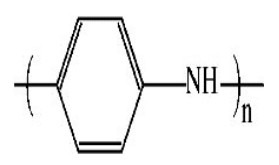

d)

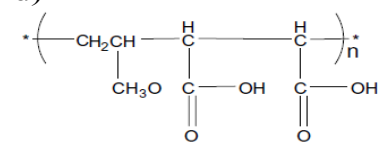

Figure 1. Chemical structure of a) PVDF, b) PANI, c) Silicone rubber and, d) PMVEA

\section{Materials}

\section{Materials and Methods}

Aniline monomer, poly (methyl vinyl ether-alt-maleic acid) (PMVEA), of MW 216,000 g/mol and ammonium persulfate (APS) were obtained from Aldrich Chem. Co. The microporous polyvinylidene fluoride (PVDF) membrane $(0.1 \mu \mathrm{m})$ was purchased from Hangzhou ANOW Microfiltration Co. Ltd., China. Liquid silicone elastomer was purchased from Portal Trading, Penang, Malaysia. N-hexane and hydrochloric acid (HCl) were supplied by Merck and used as received.

\section{Preparation of PVDF/silicone membranes}

The commercial microporous PVDF membranes were kept in a desiccator for overnight and weighed. Next, the membranes were dipped in 50\% ethanol solution for $1 \mathrm{~min}$ and washed with ultrapure water to loosen the shrunken membrane pores due to the long-term storage [34]. The dipped membranes were then coated with a mixture of 3 wt. $\%$ of silicone (with curing agent) and $97 \%$ n-hexane for 30 minutes. This was to ensure that membrane surface has been completely covered by the mixture of silicone and curing agent [19]. The ratio of silicone to curing agent was fixed at 10:1.The silicone coated layer membranes were then cross-linked with each other by keeping the silicone coated membranes in an oven at $60{ }^{\circ} \mathrm{C}$ for 1 hour [21].

\section{Multilayer membrane composites}

The microporous PVDF coated with silicone rubber were further coated with PANI in presence of polymeric acid from PMVEA to enhance the performance of the multilayer coated membranes for application in pressure filtration especially in UF and NF range. The polymerization of PANI onto the silicone coated PVDF support was performed by sandwiching aniline/PMVEA and APS aqueous solutions in a specially fabricated two-compartment cell via diffusion technique. The schematic diagram of the cell is presented in Figure 2. Silicone elastomer, which was initially coated on PVDF microporous support, was clamped in between the two cell loaded with aniline and APS aqueous solutions, respectively, in a way to enhance the absorption of PANI/PMVEA onto the microporus PVDF/silicone support. Initially, $0.8 \mathrm{~mol} . \mathrm{L}^{-1}$ aniline and $4 \mathrm{wt} . \%$ PMVEA were dissolved in $1 \mathrm{M} \mathrm{HCl}$ while the molar ratio of APS to aniline in the final solution was set at 1: $1.25 \mathrm{~mol}^{\mathrm{mol}}{ }^{-1}$. The stirring speed was maintained at $400 \mathrm{rpm}$ and a stainless steel ring clamp was used to tighten the two compartment cells where the membrane was placed in the middle of the cells. During the polymerization period, aniline/PMVEA and APS oxidant solutions were allowed to counter-diffuse, simultaneously, through the silicone/PVDF coated membrane. After the polymerization reaction for $6 \mathrm{~h}$ completed, the multilayer composite membrane was removed from the cell, cleaned with ultrapure water several times and further soaked in $1 \mathrm{M} \mathrm{HCl}$ for 24 hours to achieve a complete protonation and doping of PANI in the membranes [6]. 


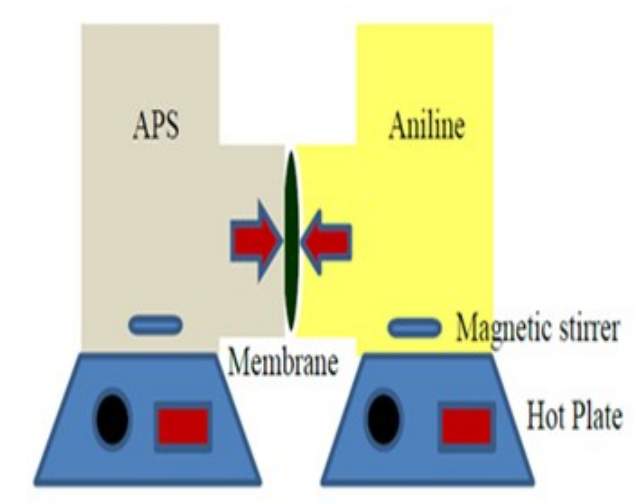

Figure 2. Schematic diagram of the two-compartment cell

PANI deposition levels in the base membranes were measured by using the gravimetric technique. The PANI deposition was calculated by measuring the weight difference between the modified and silicone/PVDF membranes. The PANI/PMVEA deposition \% PANI was calculated using Equation (1):

$$
\text { PANI/PMVEA }(\%)=\frac{\mathrm{Wf}-\mathrm{Wi}}{\mathrm{Wf}} \times 100
$$

where, $\mathrm{W}_{\mathrm{i}}$ is the initial weight of PVDF/silicone membrane before PANI/PMVEA coating and $\mathrm{W}_{\mathrm{f}}$ is the final weight of the multilayer membrane after polymerization.

\section{Membranes characterization}

Fourier transform infrared spectroscopy (FTIR) spectra of the multilayer membranes were recorded using Thermo Scientific, Nicolet 6700 FT-IR (ATR) at a resolution of $4 \mathrm{~cm}^{-1}$ using pressed potassium bromide (KBr) pellets in a transmittance mode. A wavenumber between 4000 to $600 \mathrm{~cm}^{-1}$ was scanned for 16 times with the scan time of 1 $\min$.

The surface and cross-sectional morphology of the multilayer membranes were examined with Scanning Electron Microscopy (SEM) (Leo $1550 \mathrm{VP}$ ) using activation voltage ranging from $2 \mathrm{kV}$ to $5 \mathrm{kV}$. For cross-sectional morphology, the membranes were initially dipped in liquid nitrogen to crack the membrane. All membranes were coated with gold with thickness of $6 \mathrm{~nm}$ by using Polaron SC 500 prior to analyses. Samples were mounted on a Aluminium stub and further analyzed in SEM.

Meanwhile, the thermal investigation of the membranes was measured using DSC under an inert static flowing of nitrogen gas. The temperature was increased at a rate of $10{ }^{\circ} \mathrm{C} \mathrm{min}-1$ with temperature range between $25{ }^{\circ} \mathrm{C}$ to $500^{\circ} \mathrm{C}$.

Easy Drop Goniometer (Kruss GmbH, Germany) was used to determine the membranes' contact angle $\left({ }^{\circ}\right)$ via dropping a water droplet with a volume of $2 \mathrm{~mL}$ onto the film surface and a high speed camera was used to record the droplet permeation images. The measurements were carried out in air at room temperature. At each activation potential, an average contact angle was determined from measurements of 3 separate droplets within a region of 2 $\mathrm{mm}^{2}$.

Sterlitech HP4750 Stirred Cell was used to obtain the water flux and the rejection of the synthesized membrane having an active surface area of $14.6 \mathrm{~cm}^{2}$ using Equation (2) $[33,35,36]$. Membrane water filtration properties were determined by using pure water flux measurement at pressure ranged from 1 to 5 bar at $27^{\circ} \mathrm{C}$.

$$
\text { Flux, } \mathrm{J}=\frac{\mathrm{V}}{\mathrm{Axt}}
$$


where, $\mathrm{J}$ is the permeate flux $\left(\mathrm{L} \cdot \mathrm{m}^{-2} \cdot \mathrm{h}^{-1}\right), \mathrm{V}$ is volume of permeate $(\mathrm{L}), \mathrm{A}$ is effective membrane area $\left(\mathrm{m}^{2}\right)$ and $\mathrm{t}$ is operating time (h).

Molecular weight cut-off (MWCO) value was obtained from the PEG rejection profile of the multilayer membranes from $90 \%$ molecular rejection which were calculated using Equation (3). Solute rejection (SR) of the multilayer membranes were evaluated with various MW of PEG solutions from 6000 to 20000 g.mol ${ }^{-1}$ with concentration of $100 \mathrm{mg} . \mathrm{L}^{-1}$ at 5 bar.

$$
\operatorname{SR}(\%)=\left[1-\frac{\mathrm{Cp}}{\mathrm{Cf}}\right] \times 100
$$

$\mathrm{C}_{\mathrm{f}}$ and $\mathrm{C}_{\mathrm{p}}$ are the polyethylene glycol concentrations in the feed solution and permeate solution, respectively [37]. The concentration of PEG was determined based on their absorbency in a UV-spectrophotometer at a wavelength of $535 \mathrm{~nm}$.

\section{Gravimetric PANI/PMVEA content}

\section{Results and Discussion}

PANI/PMVEA deposition amount in the based membrane supports were measured by using the gravimetric technique. The PANI/PMVEA coated onto the composite membrane support was calculated by measuring the weight difference between modified and coated PVDF membranes with silicone elastomer (Table 1). The results showed that longer reaction time resulted in higher PANI deposition onto the membrane to form the PANI/PMVEA multilayer membrane. The highest PANI/PMVEA coating of $61.8 \%$ was obtained at 10 hours while the lowest of $32.4 \%$ was obtained at 6 hours. In this work, PANI/PMVEA was assumed to be deposited inside the pores and on the surface of the silicone/PVDF membrane during the polymerization period in the two-compartment cell (refer Figure 2). PANI has formed in bulk membrane by the counter-diffusion of aniline and oxidant (APS) through the membrane [6]. The amount of PANI/PMVEA deposited onto the membrane was calculated via gravimetry technique. During the polymerization process, PANI deposition was initiated on the aniline-facing side of the membrane and maintained its asymmetric growth in the bulk membrane throughout the polymerization.

Table 1. The amount of PANI/PMVEA deposited (\%) onto silicone/PVDF

\begin{tabular}{cc}
\hline $\begin{array}{c}\text { Polymerisation Time } \\
\text { (h) }\end{array}$ & $\begin{array}{c}\text { PANI/PMVEA Deposition } \\
\text { (\%) }\end{array}$ \\
\hline 6 & 32.4 \\
8 & 40.0 \\
10 & 61.8 \\
\hline
\end{tabular}

Donnan exclusion may be used to explain the deposition mechanism of PANI onto microporous support in the diffusion cell [38]. In the polymerization period using the two-compartment cell, APS solution was used in the compartment with ANI. The negatively charged $\mathrm{S}_{2} \mathrm{O}_{8}{ }^{2-}$ species would then be generated from the decomposition of APS on the support polymer. This resulted in the polymerisation of PANI from positively charged anilinium ions $\left(\mathrm{C}_{6} \mathrm{H}_{5} \mathrm{NH}^{3}+\right)$ onto the ANI-facing side of the diffusion cell. This occurred right after the mixing of the monomer and oxidant attached to the microporous support sites. Subsequently, the PANI polymerisation would be enriched on the surface of the ANI-facing side of the membrane, through a continuous polymerisation process with a counter diffusion of ANI and APS with time. The surface coverage and in-bulk PANI deposition increased with the polymerisation time.

Similar phenomenon was observed upon coating of PANI onto other supports. The difference in coating amount between the supports over the time can be explained by the difference in the support layer's interaction with PANI (the in-situ chemical oxidative polymerisation of PANI onto PVDF has been reported to be inhibited by the nature 
of the PVDF matrix compared to polyethylene terpthalate (PET)) [39]. High amounts of PANI coating have also been reported for PET [39] and Nylon 6 [40] supports. This indicates that it is the physicochemical interaction of ANI with the hydrogen bonding of the $\mathrm{NH}_{2}$-group of the ANI molecule with the silicone/PVDF that plays the role, as this is similar to the interaction with the carboxyl group in PET [39] and Nylon 6 [40]. Thus, in presence of silicone layer, it is assumed that the coating would be much better on the membrane support rather than directly coated onto the pure PVDF surface.

\title{
FTIR analysis
}

Figure 3 shows the FTIR spectra of the PANI/PMVEA multilayer membranes in comparison to the PVDF and silicone/PVDF coated membranes. The main peaks at 1588 and $1584 \mathrm{~cm}^{-1}$ correspond to the $\mathrm{C}=\mathrm{C}$ stretching deformation of quinoid and benzenoid rings, respectively. The $1259.7 \mathrm{~cm}^{-1}$ band is assigned to the $\mathrm{C}-\mathrm{N}$ stretching of the secondary aromatic amine. The peak at $796.1 \mathrm{~cm}^{-1}$ is assigned to an out-of-plane deformation of C-H in the 1,4disubstituted benzene ring. A peak at $1291.9 \mathrm{~cm}^{-1}$, ascribed to the $\mathrm{C}-\mathrm{N}^{+}$stretching vibration in the polaron structure, is also observed, indicating that the PANI is in a doped state [31]. In addition to the common peaks representing PANI, a peak at $1716.5 \mathrm{~cm}^{-1}$ that belongs to the $\mathrm{C}=\mathrm{O}$ stretching vibration of a carboxylic acid group is seen in the spectra of PANI-PMVEA indicating the presence of the polymeric acid (PMVEA) that was incorporated into the PANI structure.

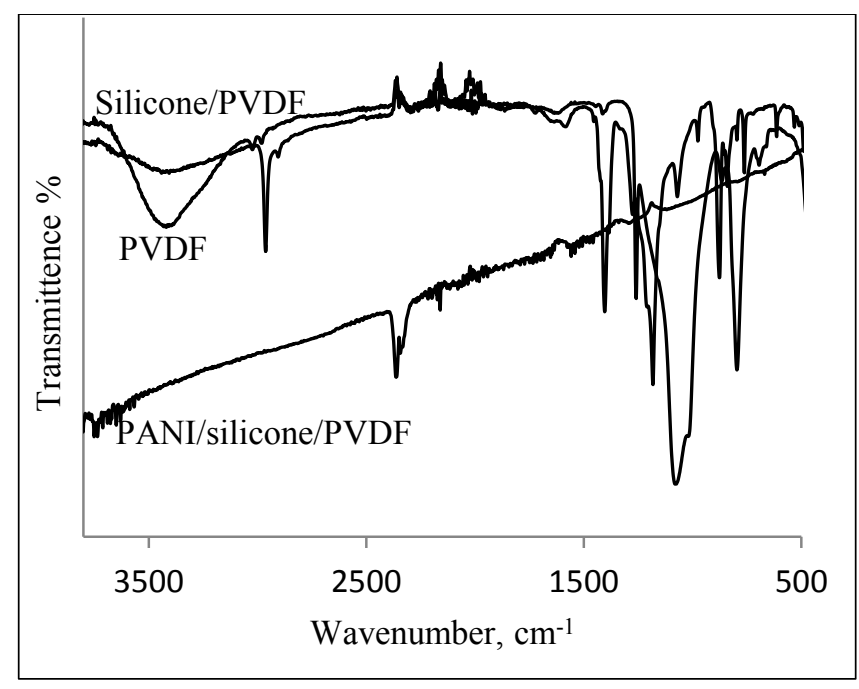

Figure 3. vFTIR spectra for the PANI/PMVEA, silicone/PVDF, PVDF multilayer composite membranes

\begin{abstract}
Morphology of multilayer membranes
SEM images of the PANI/PMVEA composite membrane obtained from the chemical oxidation of aniline are shown in Figure 4. The images reveal that the molecular structure of the PVDF without coating is totally different with the PVDF/silicone. Figure 4(b) shows the silicone structural image on the surface of the PVDF membrane. The images of the coated PANI/PMVEA at different (\%) in Figure 4(c), 4(d) and 4(e) are found to possess lumpy and granular morphological structures and the PANI/PMVEA growth seems to be bigger at a higher polymerisation time. From these three images, a better deposition of PANI/PMVEA can be seen in Figure 4(c) and 4(d) compared to 4(e) although higher PANI/PMVEA content was obtained at 10 hours polymerization time (refer Table 1). The more reaction times are taken for polymerization, the more PANI/PMVEA is coated on the silicone/PVDF surface.
\end{abstract}

From the SEM images, the morphology of PVDF membranes have changed after silicone elastomer is coated onto them. The polymerisations of PANI/PMVEA onto the micro-supports have altered the morphology of silicone elastomer onto PVDF. The molecular structure of the multilayer membrane is also affected by polymeric acid 
involved and the properties of oxidant (APS) which is hydrophilic [31]. The formation of molecular structure happens through hydrogen bonding and hydrophilic/hydrophobic interaction that act as a template. The scanning electron micrograph in Figure 4(a) shows the surface morphology of the PVDF support. The surface was smoother compare the pristine PVDF (Figure 4(a)). The PVDF/silicone (Figure 4(b)) is rougher but the roughness of $\mathrm{PVDF} /$ silicone/PANI is lesser than the PVDF/silicone after coated with PANI. The deposition of PANI/PMVEA layer on the membrane support increases with the polymerisation time [6].

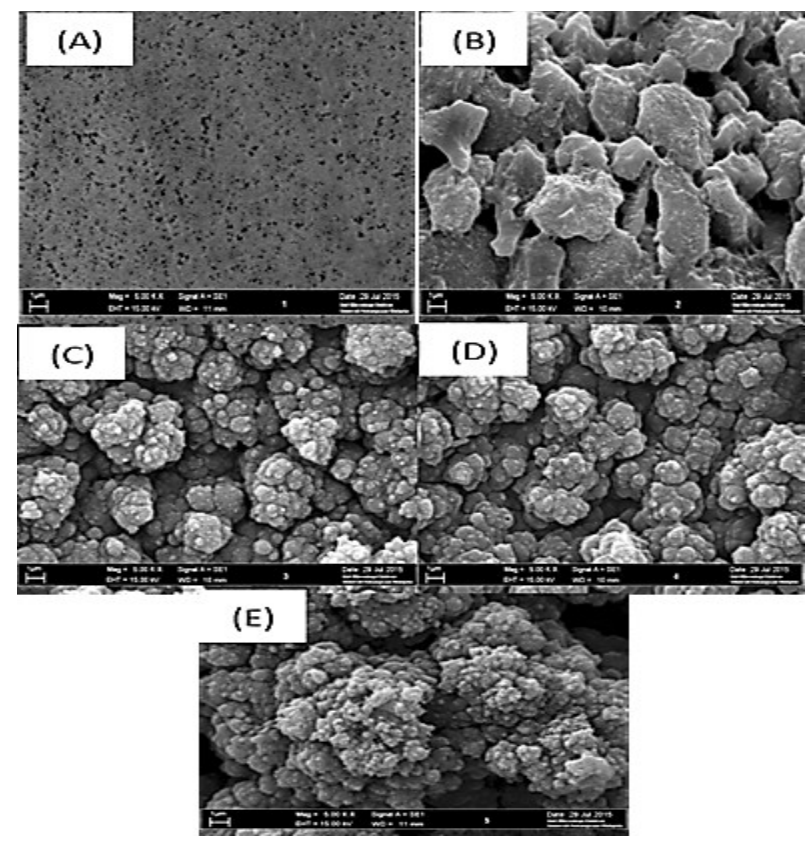

Figure 4. SEM surface images obtained; (a) PVDF support, (b) silicone/PVDF support, (c) PANI/silicone/PVDF 6 $\mathrm{h}(50 \%)$, (d) PANI/silicone/PVDF $8 \mathrm{~h}(63.3 \%)$ and (e) PANI/silicone/PVDF $10 \mathrm{~h}(83.3 \%)$ with the PMVEA, Magnification $5000 \mathrm{x}$.

\section{Contact angle (CA) analysis}

The contact angle (CA), $\theta$, of a liquid drop on a solid surface is a useful measurement of the interactions at the solid-vapor, solid liquid, and liquid-vapor interface. The surface tension of a material determines its wettability. Typically, high CA values are an indication of low wettability, whereas low CA values correspond to high wettability [24,41]. Table 2 shows the equilibrium values of contact angle onto the membrane. The different contact angle shows the wettability of the membrane either possesses hydrophilic or hydrophobic characteristic. Based on the table, the coated membrane with PANI at all different polymerisation time has completely changed their characteristic of the PVDF/silicone support used from hydrophobic to hydrophilic properties. The contact angles recorded at $0^{\circ}$ for the newly synthesized membrane shows that it possesses super-hydrophilic properties based on the lowest contact angles recorded. This is probably because the membranes were doped with $1 \mathrm{M} \mathrm{HCl}$ that protonate the PANI, and give the highest contact angle value. This result indicates a preliminary data for the pressure filtration of the membrane, which would be highly permeable in water. Therefore the flux is expected to be high thus a good membrane is produced. The membrane flux value is presented in the following section. 
Fatimah et al: POLYANILINE MULTI-COATED ONTO POLYVINYLIDENE FLUORIDE AND SILICON

ELASTOMER FOR PRESSURE FILTRATION MEMBRANES

Table 2. Contact angle values of the different form membranes

\begin{tabular}{lc}
\hline Sample & Contact Angle $\left.\mathbf{(}^{\circ}\right)$ \\
\hline PVDF & 78.8 \\
Silicone/PVDF & 143 \\
PANI-PMVEA/silicone/PVDF & \\
6 hours & 0 \\
8 hours & 0 \\
10 hours & 0 \\
\hline
\end{tabular}

\section{Thermal properties of multilayer membrane}

Figure 5 shows the melting temperatures of PVDF and PANI/silicone/PVDF composites membranes at different PANI content. The DSC curve peaks indicates the endothermic processes, where energy is required to break the bonds in the successive elimination of $\mathrm{H}_{2} \mathrm{O}, \mathrm{CO}$ and $\mathrm{CO}_{2}$. The first peak is the evaporation of moisture and residual organic solvent in the membrane. The second peak is the endothermic process of the loss of the doping acid instead of a glass transition [42]. The sharp melting peak of PVDF is observed at $250{ }^{\circ} \mathrm{C}$. The peaks representing PANI and silicon rubber is observed at 280 and $170{ }^{\circ} \mathrm{C}$, respectively. The elimination of water molecules can be clearly seen at $100{ }^{\circ} \mathrm{C}$ especially for the PANI coated membranes. This is because PANI membrane in the form of emeraldine (doped with acids) carries high hydroxyl molecules, which will be evaporated at their boiling temperature. Meanwhile no shift in the peaks were observed for the major components of PVDF, PANI and silicone indicating the stability of the components used to produce the membrane.

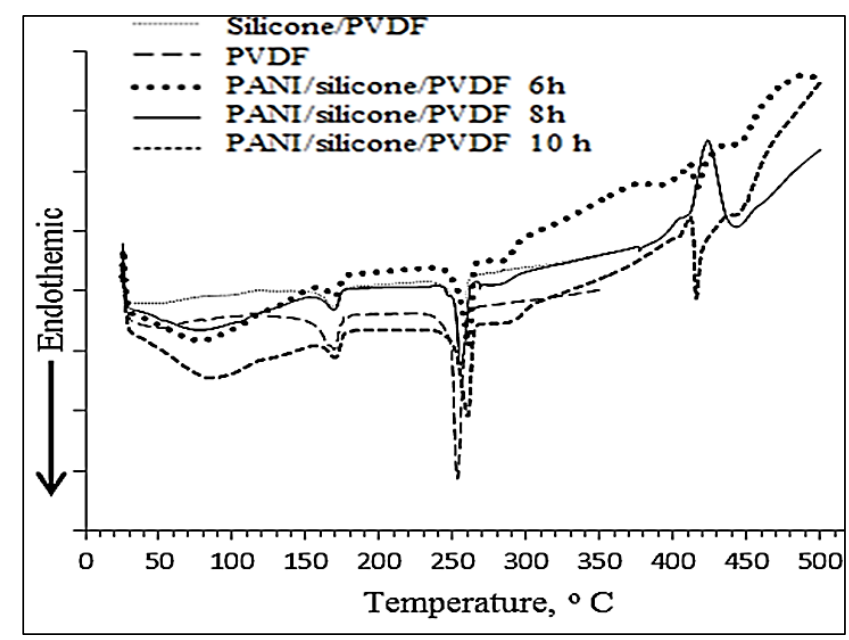

Figure 5. DSC for the different polymerization times of multilayer membranes

Based on the physical, chemical, morphological and thermal properties of the membranes analyzed in this work, the synthesized membranes are found to possess reasonable properties suitable for the application in pressure filtration. For example, the contact angles of the membranes have shown super-hydrophilic properties upon addition of the PANI/PMVEA indicating high water permeation and flux. The presence of PANI/PMVEA is supported by the FTIR, SEM and DSC analysis. Though the intrinsic properties of the membranes are confirmed from these analyses, the best membrane that could be used for pressure filtration at different polymerization time is yet to be identified. Further characterization for the membrane performances in pressure filtration is presented in the next section. 


\section{Multilayer pressure filtration membrane test}

The permeation performances of the synthesized membranes were investigated by the water flux and the PEG rejection. Figure 6 and Table 3 show the respective variation of flux and rejection profile for membrane with different polymerization times performed at different pressure. Figure 6 shows the PANI membrane produced at 6 hours polymerisation has high water flux followed by the membranes produced at 8 and 10 hours, respectively. The highest water flux was recorded at the lowest polymerisation time of 6 hours. This result is supported by the membrane morphological properties with higher PANI \% that have a tighter structure resulting in a lower flux value.

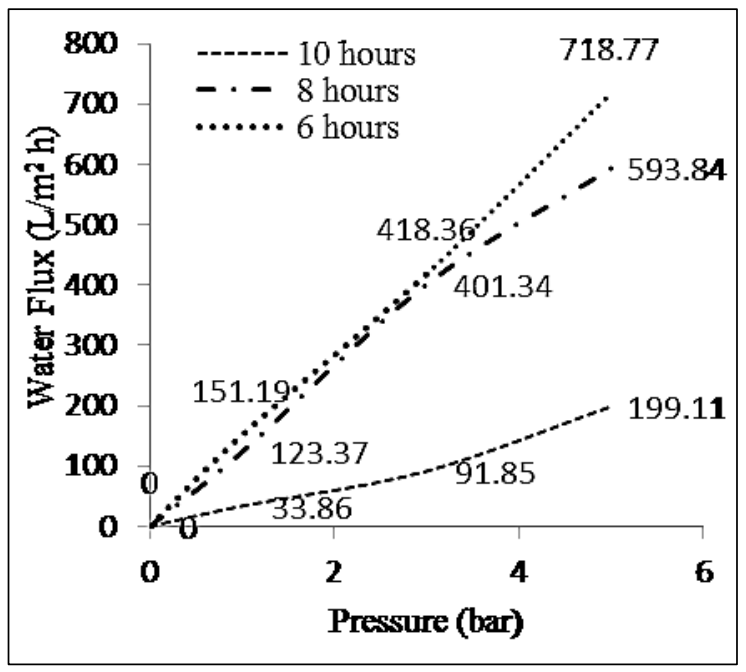

Figure 6. Water flux of multilayer filtration membrane

Table 3. Rejection of PEG below 20,000 g/mol

\begin{tabular}{|c|c|c|c|c|c|}
\hline \multirow[t]{2}{*}{$\begin{array}{c}\text { PANI Content } \\
\%\end{array}$} & \multirow{2}{*}{$\begin{array}{l}\text { Polymerisation } \\
\text { Times } \\
\text { (h) }\end{array}$} & \multicolumn{2}{|c|}{$\begin{array}{l}\text { Permeate Flux } \\
\left(\mathbf{L} / \mathbf{m}^{2} . \mathbf{h}\right) \\
(3 \mathrm{bar})\end{array}$} & \multicolumn{2}{|c|}{$\begin{array}{c}\text { Rejection PEG } \\
(\mathrm{g} / \mathrm{mol})\end{array}$} \\
\hline & & 6000 & 10000 & 6000 & 10000 \\
\hline 32.4 & 6 & 904.1 & 799.3 & 39.3 & 18.7 \\
\hline 40.0 & 8 & 233.8 & 208.8 & 10.7 & 3.04 \\
\hline 61.8 & 10 & 297.3 & 257.5 & 39.1 & 5.81 \\
\hline
\end{tabular}

Membrane rejection at different MWs of PEG (presented in Table 3) shows that the lowest polymerisation times resulting the lowest PANI \% have a comparable rejection value with the 10 hours polymerisation time, though the PANI content \% is almost doubled for 10 hours. These results can be supported by the SEM images where the PANI deposition at higher polymerisation time than 6 hours does not help in sealing the membrane pores but has elongated the polymer on the membranes surface. It is expected that longer polymerization time supposed to form a better surface coverage. However, bigger micelles are formed and elongated (refer Figure 4 (e)). This has caused un-even coating as well as inconsistent porosity at different membrane area. The same results were reported by $[31,43]$ under extended polymerisation time causing the PANI/PMVEA to form a micelle structure and elongate on the polymer surface. Therefore the rejection is found to be not improving by prolonging the reaction time. Lower rejection is obtained possibly due to the pores leakage on the membranes at higher pressure $(5 \mathrm{bar})$ during the compaction prior to the PEG filtration. This is supported by the presence of filtration traces of PANI observed in the permeate stream 
after the compaction process. Based on this result also, it can be concluded that the membrane prepared at 6 hours possesses the highest rejection and the highest flux to be further tested for a higher MW PEG.

\section{Conclusion}

PANI/PMVEA multilayer composite membranes were fabricated by chemical polymerization in a specially fabricated two-compartment cell. The amount of PANI/PMVEA \% coated onto the silicone/PVDF support has increased with the increase in polymerisation time. The physical, chemical, thermal and morphological characteristic of the PVDF/silicone elastomer microporous support has changed in the presence of PANI/PMVEA. FTIR spectra have confirmed the incorporation of polymeric acid (PMVEA) into the PANI. DSC analysis has confirmed that the multilayer coating does not change much on the thermal stability of the membranes based on the melting peaks position. Contact angle shows that the water permeability of the membrane has twisted from hydrophobic to super-hydrophilic in presence of $\mathrm{HCl}$ doped PANI/PMVEA. The water flux of multilayer membrane decreased with the increased in PANI/PMVEA content. The higher PANI \% gave the lowest water and permeate flux. The rejection result shows that the membrane has reasonable rejection at 6 hours than 8 or 10 hours while maintaining the highest flux than the others. It is suggested by optimizing the polymerization time will enhance the rejection properties of the membrane.

\section{Acknowledgement}

The authors are thankful to the Ministry of Higher Education (MOHE) of Malaysia for their financial support under the Fundamental Research Grant Scheme (FRGS/2/2013/TK05/UKM/02/4) and the Long Term Research Grant Scheme (LRGS/2013/UKM-UKM/PT/03), Department of Chemical and Process Engineering, Universiti Kebangsaan Malaysia and MyMaster by MOSTI for the MSc scholarship.

\section{References}

1. Montazami, R., Jain, V. and Heflin, J. R. (2010). High contrast asymmetric solid state electrochromic devices based on layer-by-layer deposition of polyaniline and poly (aniline sulfonic acid). Electrochimica Acta, 56(2): $990-994$.

2. Abdolahi, A., Hamzah, E., Ibrahim, Z. and Hashim, S. (2012). Synthesis of uniform polyaniline nanofibers through interfacial polymerization. Materials, 5(8): 1487 - 1494.

3. Tokarský, J., Maixner, M., Peikertová, P., Kulhánková, L. and Burda, J. V. (2014). The IR and Raman spectra of polyaniline adsorbed on the glass surface; comparison of experimental, empirical force field, and quantum chemical results. European Polymer Journal, 57: 47 - 57.

4. Detsri, E. and Dubas, S. T. (2009). Interfacial polymerization of water-soluble polyaniline and its assembly using the layer-by-layer technique. Journal of Metals, Materials and Minerals, 19(1): 39 - 44.

5. Vivekanandan, J., Ponnusamy, V., Mahudeswaran, A. and Vijayanand, P. S. (2011). Synthesis, characterization and conductivity study of polyaniline prepared by chemical oxidative and electrochemical methods. Archives of Applied Science Research, 3(6): 147 - 153.

6. Qaiser, A. A. (2010). Electrochemical composite membranes based on intrinsically conducting polymers synthesis and characterization. University of Aucklannd: Auckland. pp. $1-192$.

7. Supri, A. G., Ammar, Z., Yeon, A., Shakaff, M., Hassan, A., Noor, M. and Ahmad, P. (2012). Enhancing conductive polymer performance using eggshell for ammonia sensor. Journal of Physical Science, 23(2): 73 83.

8. Guillen, G. R. and Hoek, E. M. (2010). Development and testing of "smart" nanofiltration membranes. University of California: Los Angeles: pp $1-46$.

9. Ali, Y., Kumar, V., Sonkawade, R. G. and Dhaliwal, A. S. (2012). Fabrication of polyaniline nanofibers by chronopotentiometry. Advance Materials Letters, 3: 388 - 392.

10. Gomes, E. C. and Oliveira, M. A. S. (2012). Chemical polymerization of aniline in hydrochloric acid ( $\mathrm{HCl})$ and formic acid $(\mathrm{HCOOH})$ media. Differences between the two synthesized polyanilines. American Journal of Polymer Science, 2(2): 5 - 13.

11. Saikia, P. J. and Sarmah, P. C. (2011). Investigation of polyaniline thin film and Schottky junction with aluminium for electrical and optical characterization. Materials Sciences and Applications, 2(8): 1022 -1026. 
12. Sapurina, I. Y. and Shishov, M. A. (2012). Oxidative polymerization of aniline: Molecular synthesis of polyaniline and the formation of supramolecular structures. Chapter in Book, Dr. Ailton De Souza Gomes (Ed.), InTech Publisher.

13. Tiwari, A. and Singh, V. (2007). Synthesis and characterization of electrical conducting chitosan-graftpolyaniline. Express Polymer Letters, 1(5): 308 - 317.

14. Jelmy, E. J., Ramakrishnan, S., Devanathan, S., Rangarajan, M. and Kothurkar, N. K. (2013). Optimization of the conductivity and yield of chemically synthesized polyaniline using a design of experiments. Journal of Applied Polymer Science, 130(2): 1047 - 1057.

15. Devi, M. G., Al Omairi, K. A. S., Feroz, S. and Ali, S. M. (2013). Treatment of textile industry effluent using multilayer thin films. International Journal of Engineering Research and Technology, 2 (7): $701-706$.

16. Sagidullin, A., Meier-Haack, J. and Scheler, U. (2005). Water diffusion through asymmetric polymer membranes and polyelectrolyte multilayers. Diffusion Fundamentals, 2: 131 - 132.

17. Ashraf, M. A., Maah, M. J., Qureshi, A. K., Gharibreza, M. and Yusoff, I. (2013). Synthetic polymer composite membrane for the desalination of saline water. Desalination and Water Treatment, 51(16-18): 3650 - 3661 .

18. Hassanien, A. M., El-Hashash, M. A., Mekewi, M. A., Guirguis, D. B.and Ramadan, A. M. (2013). Fabrication of polyvinyl alcohol/cellulose acetate (PVA/CA/PEG) antibacterial membrane for potential water purification application. Hydrology: Current Research, 4: $146-152$.

19. Ye, Z., Chen, Y., Li, H., He, G. and Deng, M. (2005). Preparation of a novel polysulfone/polyethylene oxide/silicone rubber multilayer composite membrane for hydrogen-nitrogen separation. Materials Chemistry and Physics, 94: $288-291$.

20. Shieh, J. J. and Chung, T. S. (2000). Cellulose nitrate-based multilayer composite membranes for gas separation. Journal of Membrane Science, 166: 259 - 269.

21. Chung, T-S., Shieh, J-J., Lau, W. W-Y., Srinivasan, M. P. and Paul, D. R. (1999). Fabrication of multi-layer hollow fiber membranes for gas separation. Journal of Membrane Science, 152: $211-225$.

22. Abu, S., Kim, Y. H., Kim, C., Park, Y., Gopalan, A. I., Lee, K. P. and Choi, S. J. (2013). Preparation and characterization of MWCNT-g-poly (aniline-co-DABSA)/Nafion ${ }^{\circledR}$ nanocomposite membranes for direct methanol fuel cells. Bulletin of the Korean Chemical Society, 34(9): 2657-2662.

23. Amado, F. D. R., Gondran, E., Ferreira J. Z. Rodrigues M. A. S. and Ferreira C. A. (2004). Synthesis and characterisation of high impact polystyrene/polyaniline composite membranes for electrodialysis. Journal of Membrane Science, 234(1-2): 139 - 145.

24. Blinova, N.V. and Svec, F. (2012). Functionalized polyaniline-based composite membranes with vastly improved performance for separation of carbon dioxide from methane. Journal of Membrane Science, $423-$ 424: $514-521$.

25. Zhu, J., Chen, M., Qu, H., Zhang, X., Wei, H., Luo, Z. and Guo, Z. (2012). Interfacial polymerized polyaniline/graphite oxide nanocomposites toward electrochemical energy storage. Polymer, 53(25): $5953-$ 5964.

26. Morari, C., Balan, I., Pintea, J., Chitanu, E. and Iordache, I. (2011). Electrical conductivity and electromagnetic shielding effectiveness of silicone rubber filled with ferrite and graphite powders. Progress in Electromagnetics Research M, 21: 93 - 104.

27. Achalpurkar, M. P., Kharul, U. K., Lohokare, H. R. and Karadkar, P. B. (2007). Gas permeation in amine functionalized silicon rubber membranes. Separation and Purification Technology, 57(2): $304-313$.

28. Mohamed, F., Hasbullah, H., Jamian, W. N. R., Rani, A. R. A., Saman, M. F. K., Salleh, W. N. H. W. and Ismail, A. F. (2015). Morphological investiggation of poly(lactic acid) asymmetric membrane. Journal of Engineering Science and Technology: $1-8$.

29. Saritha Chandran A. (2008). Polaniline coated short nylon fiber/elastromer composites: electrical and microwave characteristic, Thesis in Faculty of Technology, Cochin University of Science and Technology: Kerala, India.

30. Matsuura, T. (1993). Synthetic membranes and membrane separation processes. CRC press.

31. Zhang, L., Peng, H., Sui, J., Kilmartin, P. A. and Travas-Sejdic, J. (2008). Polyaniline nanotubes doped with polymeric acids. Current Applied Physics, 8(3): $312-315$.

32. Strathmann, H. (2011). Introduction to membrane science and technology. Wiley-VCH verlag \& Co, Germany. 
33. Rohani, R., Hyland, M. and Patterson, D. (2011). A refined one-filtration method for aqueous based nanofiltration and ultrafiltration membrane molecular weight cut-off determination using polyethylene glycols. Journal of Membrane Science, 382(1): $278-290$.

34. Kang, S. H. and Chang, Y. K. (2005). Removal of organic acid salts from simulated fermentation broth containing succinate by nanofiltration. Journal of Membrane Science, 246(1): $49-57$.

35. Yilmaz, F. (2007). Polyaniline: synthesis, charaterization, solution properties and composites, Thesis Polymer Science and Technology, School of Natural and Applied Sciences.

36. Jaleh, B., Gavary, N., Fakhri, P., Muensit, N. and Taheri, S. M. (2015). Characteristics of PVDF membranes irradiated by electron beam. Membranes, 5(1): $1-10$.

37. Alam, J., Dass, L. A., Alhoshan, M. S., Ghasemi, M. and Mohammad, A. W. (2012). Development of polyaniline-modified polysulfone nanocomposite membrane. Applied Water Science, 2(1): 37 - 46.

38. Iyoda, T., Ohtani, A., Honda, K., \& Shimidzu, T. (1990). Diaphragmatic chemical polymerization of pyrrole in the Nafion film. Macromolecules, 23(7): 1971 - 1976.

39. Pud, A., Ogurtsov, N., Korzhenko, A. and Shapoval, G. (2003). Some aspects of preparation methods and properties of polyaniline blends and composites with organic polymers. Progress in Polymer Science, 28(12): $1701-1753$.

40. Sung, W. B. and Im Seung, S. (1998). Physical properties and doping characteristics of polyaniline-nylon 6 composite films. Polymer, 39(2): 485 - 489.

41. Sironi, A., Marinotto, D., Riccardi, C., Zanini, S., Guerrini, E., Della Pina, C. and Falletta, E. (2015). Effect of salicylic acid and 5-sulfosalicylic acid on UV-Vis spectroscopic characteristics, morphology, and contact angles of spin coated polyaniline and poly (4-aminodiphenylaniline) thin films. Journal of Spectroscopy, 2015: $1-8$.

42. Zhang, X., Zhu, J., Haldolaarachchige, N., Ryu, J., Young, D. P., Wei, S. and Guo, Z. (2012). Synthetic process engineered polyaniline nanostructures with tunable morphology and physical properties. Polymer, 53: 2109 2120.

43. Zhang, X., Chan-Yu-King, R., Jose, A. and Manohar, S. K. (2004). Nanofibers of polyaniline synthesized by interfacial polymerization. Synthetic Metals, 145(1): 23 - 29. 